REVIEW

\title{
Perioperative Blood Management in Posterior Instrumented Fusion for Adolescent Idiopathic Scoliosis: Original Study and Short Review of the Literature
}

\author{
Lamprini Katranitsa' , Nikolaos Gkantsinikoudis ${ }^{2}$, Stylianos Kapetanakis ${ }^{2}$, \\ Georgios Charitoudis ${ }^{2}$, Anastasios Christodoulou ${ }^{1}$, Panagiotis Givissis ${ }^{1}$ \\ ${ }^{1}$ 1st Orthopaedic Department, G. Papanikolaou General Hospital, School of Medicine, Aristotle University of Thessaloniki, \\ Thessaloniki, Greece \\ ${ }^{2}$ Department of Spinal Surgery, European Interbalkan Medical Center of Thessaloniki, Thessaloniki, Greece
}

\section{Correspondence: \\ Lamprini Katranitsa, 1st Ortho- paedic Department, G. Papaniko- laou General Hospital, School of Medicine, Aristotle University of Thessaloniki, Exohi, 57010 Thes- saloniki, Greece \\ E-mail: katranitsalamprini@gmail. com \\ Tel: 00306944838199}

Received: 04 Sept 2017

Accepted: 06 Oct 2017

Published Online: 20 Nov 2017

Published: 30 June 2018

Key words: scoliosis, transfusion, blood management, cell saver, autologous blood predeposition

Citation: Katranitsa L, Gkantsinikoudis N, Kapetanakis S, Charitoudis G, Christodoulou A, Givissis P. Perioperative blood management in posterior instrumented fusion for adolescent idiopathic scoliosis: an original study and short review of the literature. Folia Med (Plovdiv) 2018;60(2):200-7.

doi: 10.1515/folmed-2017-0100
Background: The potential hazards of allogeneic blood transfusion are well established in literature. Few things are known, however, about the results of combining different blood saving techniques and their results in avoiding allogeneic blood transfusion (ABT) in scoliosis surgery.

Aim: To report specific results about utilization of preoperative autologous blood donation (PABD) and intraoperative blood-saver (BLDS) in conjunction, aiming to minimize the need for $A B T$.

Materials and methods: Between 1989 and 2012, 107 patients underwent posterior instrumented fusion (PIF) for adolescent idiopathic scoliosis (AIS) correction. Retrospective evaluation was conducted. Patients were classified into two groups, according to the method utilized: group A with only allogeneic blood transfusion $(A B T)$ and group $B$ where PABD with BLDS intraoperatively was applied. Hematocrit and hemoglobin values were evaluated preoperatively, postoperatively, and at discharge. The variables we examined included also gender, age, levels fused and number of predeposited blood units, required transfused blood units (TBU), as well as $A B T$ rates between the two groups.

Results: More than $70 \%$ of the transfusions in both groups were needed intraoperatively. In group A, an average of 2.4 units per patient was transfused and ABT reached $76 \%$. In contrast, in group $B$ an average of 4.5 units per patient was transfused but $A B T$ rate was only $7.3 \%$, while the rest $92.7 \%$ was autologous blood. However, the wasted autologous blood reached $24.9 \%$.

Conclusions: Our results demonstrated that PABD with intraoperative cell salvage (CS) is associated with statistically significant $A B T$ rates decrement but the combination of these methods cannot assure ABT avoidance.

\section{BACKGROUND}

Posterior instrumented fusion (PIF) surgery for adolescent idiopathic scoliosis (AIS) is unfavorably associated with substantial blood loss. ${ }^{1-3}$ Allogeneic blood transfusion (ABT) emerges as a fundamental necessity in this situation. Nevertheless, ABTs are associated with significant increase of perioperative morbidity. ${ }^{4}$ Transmission of viral diseases (HBV, HCV and HIV), as well as effects on the immunological function are considered responsible for transfusion-related acute lung injury (TRALI), postoperative bacterial infections and hemolytic transfusion reactions. ${ }^{3,4}$ The above are the major adverse effects of ABT, which is also considered to have a remarkable impact on socioeconomics being related to significant costs. ${ }^{5}$

ABT avoidance represents thus a veritable requisiteness. Various techniques have emerged in recent years in this field. ${ }^{5}$ Preoperative assessment of hemoglobin ( $\mathrm{Hb}$ ) levels, abdominal compression prevention with proper patient positioning, hypotensive anesthesia and conduction of assiduous intraoperative hemostasis, as well as pharmacologic agents utilization may be implemented by spine surgeons. ${ }^{5,6}$ 
Preoperative autologous blood donation (PABD) and intraoperative blood salvage with Cell-Saver systems are pioneer methods for blood conservation in scoliosis surgery. ${ }^{6,7}$ Effectiveness of these techniques in $\mathrm{ABT}$ potentiality decrement has been extensively studied in current literature. ${ }^{2,3,8-11}$ However, none of these studies reported any particular results about utilization of these techniques in conjunction, in terms of altering ABT rates.

The aim of the present study was to publish specific results concerning the use of PABD in combination with intraoperative cell salvage (CS) in patients treated for AIS with posterior instrumented fusion, enrolling a relatively wide population size. Particular emphasis is put on ABT potentiality and perioperative blood management, as well as the percentage of autologous blood wasted. A short review of the literature regarding PABD and intraoperative CS utilization was conducted in parallel.

\section{MATERIALS AND METHODS}

\section{POPULATION CHARACTERISTICS}

The patients recruited in this study were diagnosed with AIS, with indication for PIF, completing all current indications. All operations were performed by the same senior spine surgeon. Patients were duly informed about the study aims and scope and gave written consent to participate. Approvals from the Hospital Institutional Review Board and local ethics committee were also obtained. Moreover, all aspects of this study were in accordance with the ethical principles stated in the Declaration of Helsinki.

\section{INCLUSION AND EXCLUSION CRITERIA}

Inclusion criteria: (i) Clinical diagnosis of AIS, (ii) PIF indications completed, (iii) operation performed by the senior spine surgeon in the hospital.

Exclusion criteria: (i) disc herniation, (ii) vertebral fractures, (iii) other types of scoliosis, (iv) previous spinal surgery or revision surgery, (v) hemostatic disturbances, (vi) AIS corrected from other spine surgeons in the hospital.

\section{Methods AND STUDY DESIGN}

A total of 107 patients were subjected to PIF for AIS in two different institutions from the same senior spine surgeon (A.G.C.) between 1989 and 2012. PIF is the standard surgical treatment for scoliosis. Indications for PIF were curves larger than $50^{\circ}$, with thoracic rib hump and/or lumbar prominence, with affected pulmonary function. ${ }^{24}$ All-pedicle screw constructs were used since they have shown superior radiographic correction versus hook and hybrid constructs. ${ }^{25}$

An age and number of levels fused match was performed between the two groups except for 21 patients thus finally 86 were included. All patients were retrospectively studied and allocated to two groups: group A (25 patients) which received only ABT (control group), and group B (61 patients) where PABD was performed in conjunction with intraoperative CS. PABD was based on a weekly collecting schedule, with one month duration, collecting and processing a total of 3.6 blood units on average per patient. CS was only intraoperatively performed and not postoperatively. Specialized in CS systems manipulation medical personnel postoperative absence, as well as no postoperative drainage recruitment excluded the possibility of postoperative CS system utilization. Furthermore, type and technical characteristics of the analogous device recruited for CS featured a significant differentiation among the patients. Initial purpose was to mobilize the same CS system for all patients. However, technical issues as approval of each individual Social Security Funds instituted a remarkable obstacle in this aim. Social Security Funds approval was obtained, also the commercial features of utilized CS system. As a consequence, CS systems were not used for all patients. Moreover, different commercial types on terms of label and model of CS system were utilized for patients in group B. Etiologies as particularly low BMI and distant residence place constituted a fundamental impediment in PABD wide implementation.

\section{Surgical Procedure}

Patients were preoperatively prone positioned, with subsequent middle incision and posterior spine elements exposure. Pedicle screw insertion and prebent rods positioning instituted the subsequent steps. Correction maneuvers were performed when necessary. Rods stabilization and transverse rods positioning were done after satisfactory correction was achieved. Wound suture was performed. No postoperative drainage was done. Meticulous hemostasis was undertaken in all surgical stages.

Intraoperative blood management was co-decided by anesthesiologist and spine surgeon. Transfusion limit was determined at $\mathrm{Hb}$ level of $9 \mathrm{~g} / \mathrm{dl}$. Postoperative hemodynamic evaluation revealed an $\mathrm{Hb}$ level of $10 \mathrm{~g} / \mathrm{dl}$ on average. Patients were mainly mobilized in postoperative day 2 , and discharged on postoperative day 15 on average. 


\section{STATISTICAL ANALYSIS}

Statistical analysis of data was performed with version 23.00 (SPSS Inc, Chicago, IL). Continuous variables were presented as mean \pm standard deviation (SD) and categorical variables as percentages. The Student's $t$-test for independent samples and the Mann-Whitney test were used for statistical analysis of continuous parameters when normal distribution was present and absent, respectively. Analysis of variance (ANOVA) and post-hoc Bonferroni test were used for assessment of between-group differences. In contrast, population differentiation evaluation was conducted with Wilcoxon test. Logistic regression was also performed in order to identify particular potential predictors of intraoperative hemorrhage volume.

\section{RESULTS}

Demographic and surgical characteristics of the two groups are shown in Table 1. A slight statistically significant difference between these baseline parameters was observed only for BMI demonstrating the comparability of the two groups.
Perioperative blood management featured a remarkable differentiation in the two groups. The patients in group A received allogeneic blood and $76 \%$ of them needed transfusion (mean 2.4 units). However, there were six patients $(24 \%)$ who didn't need any kind of transfusion. $71.7 \%$ of the allogeneic blood transfusions (1.7 units) was needed intraoperatively, whereas the remainder $28.3 \%$ (0.7 units) postoperatively (Fig. 1). In contrast, all patients in group B were transfused but ABT was not required for the majority of them since $92.7 \%$ of the blood transfusions was autologous. These patients received on average 4.5 blood units, being transfused with 3.5 units (76.9\%) intraoperatively and one unit postoperatively (23.1\%) but allogeneic blood was only $7.3 \%$ of the total transfusion requirements. Intraoperative CS accomplished an average re-transfusion of $372.6 \mathrm{ml}$ of blood. Considering that $300 \mathrm{ml}$ blood is quantitatively equal with one blood unit, intraoperative CS was associated with intraoperative re-transfusion of 1.3 blood units, which is $28.1 \%$ of total transfused blood quantity (Fig. 2).

Table 1. Baseline demographic and surgical characteristics of studied patients

\begin{tabular}{lccc}
\hline \multicolumn{1}{c}{ Variable } & Group A & Group B & p value \\
\hline Enrolled patients & $25(29.1 \%)$ & $61(70.9 \%)$ & - \\
Gender & $9(36 \%)$ & $12(19.7 \%)$ & 0.109 \\
$\quad$ Males & $16(64 \%)$ & $49(80.3 \%)$ & \\
$\quad$ Females & $15.8 \pm 2.24$ & $16.5 \pm 2.35$ & 0.054 \\
Age (yrs) & $18.25 \pm 3.27$ & $19.68 \pm 2.74$ & $\mathbf{0 . 0 3 4}$ \\
BMI & $287.5 \pm 68.38$ & $275.51 \pm 64.97$ & 0.455 \\
Operation duration (min) & $10.16 \pm 3.02$ & $9.62 \pm 1.85$ & 0.14 \\
Number of levels fused & $18.24 \pm 15.52$ & $16.75 \pm 9.79$ & 0.596 \\
Hospitalization duration (days) & & &
\end{tabular}

Statistically significant $\mathrm{p}$ values are shown in bold. Level of significance was defined at $\mathrm{p}=0.05$.

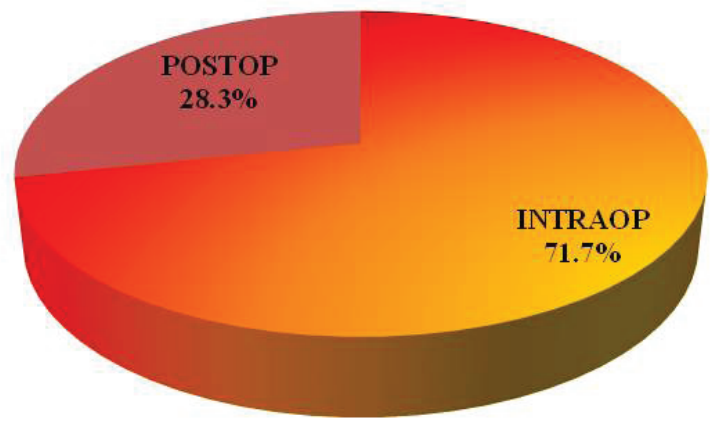

Figure 1. Group A - Transfusion requirements.

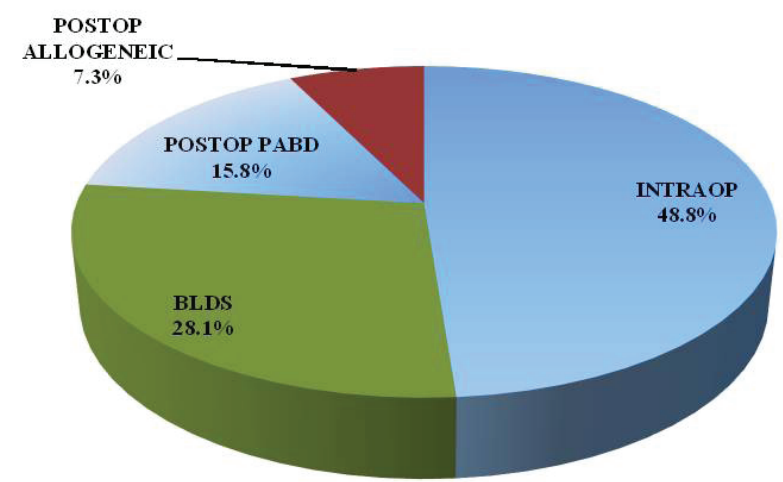

Figure 2. Group B - Transfusion requirements. 
In group A, $76 \%$ of the patients were transfused and all the transfusions were allogeneic blood. On the contrary, in group B all patients required transfusion but only $7.3 \%$ was $\mathrm{ABT}$, while the rest 92.7\% was autologous blood transfusions. Therefore, combination of PABD with intraoperative CS was capable of important ABT rates decrease. However, elimination of $\mathrm{ABT}$ requirements was not possible (Fig. 3). Moreover, the wasted autologous blood reached $24.9 \%$, since out of a total of 229 autologous blood units that were collected with PABD method 57 were not transfused.

Impact of PABD and CS in hemodynamic condition was studied measuring the Hct and $\mathrm{Hb}$ levels. These indexes were calculated preoperatively, postoperatively, and at discharge of patients. Preoperatively, Hct level was 39.8 in group A and 35.3 in group $\mathrm{B}$. In addition, preoperative $\mathrm{Hb}$ levels were $13.1 \pm 1.7$ and $11.6 \pm 1.1$, respectively. This

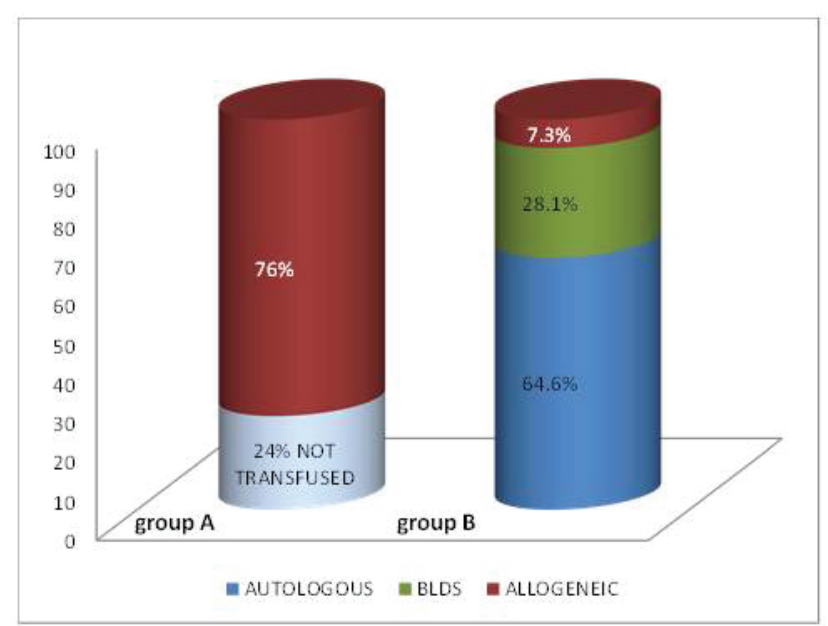

Figure 3.

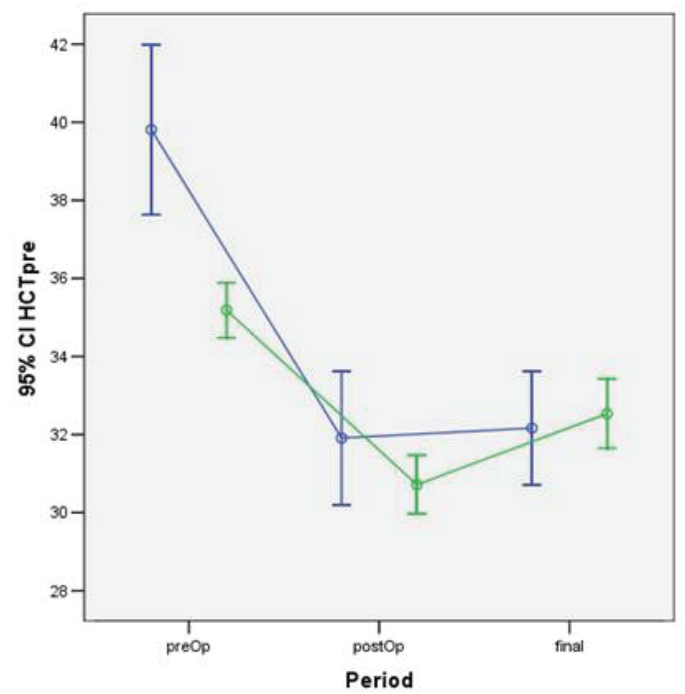

Figure 4. difference was statistically significant for these two variables $(p<0.001)$. Hb levels differentiation among the different chronic intervals is presented in Fig. 4. Hct and $\mathrm{Hb}$ levels were similar between the two groups postoperatively and at discharge.

\section{DISCUSSION}

Blood loss constitutes a noteworthy surgical issue in scoliosis surgery. ${ }^{2}$ Perioperative blood management is therefore of substantial importance. ABT is associated with potential hazardous complications and, thus, ABT avoidance with blood conservation methods recruitment should institute a fundamental priority. $^{5}$

PABD and intraoperative CS with Cell-saver systems are widely utilized for blood conservation in PIF for AIS in recent years. , $^{3,10,12}$ However, much controversy exists in current literature about these methods' safety and efficacy, in terms of decreasing ABT potentiality.

PABD favorable impact on reducing ABT rates remains still controversial (Table 2). Sanpera et al. ${ }^{10}$ retrospectively studied 37 patients, concluding that PABD implementation resulted in more significant transfusion potentiality intraoperatively, which is in accordance with our study. In addition, a worth mentioning portion of autologous blood was not utilized. In our study, 57 of the 229 predonated autologous blood units were wasted, representing $24.9 \%$ of the collected autologous blood. PABD was thus theorized to be downgraded in terms of costeffectiveness. ${ }^{10}$ This thesis was also advocated from other studies, demonstrating that PABD is associated with considerably high intraoperative transfusion rates and significant procedure costs. ${ }^{8,13,14}$ On the contrary, Ridgeway et al. prospectively studied 45 patients, stating that PABD is related to remarkable decrement of ABT potentiality. ${ }^{8}$ Boniello et al. reported the same conclusion, speculating also that PABD is not primarily culpable for preoperative Hct levels abatement. ${ }^{9}$ Moreover, conjunction of PABD with other blood conservation techniques may further decrease the ABT rates. ${ }^{15}$

Intraoperative CS with Cell-saver institutes a well-established method for blood conservation in AIS surgery. ${ }^{7}$ The overwhelming majority of literature reports advocate that Cell-saver intraoperative recruitment is associated with a remarkable decrement in intraoperative blood transfusion potentiality (Table 3). ${ }^{2,3,11,16-19}$ Postoperative clinical outcomes are not unfavorably affected with Cell-saver utilization. ${ }^{17}$ Oliveira et al. argued that CS utilization was 
Table 2. PABD utilization outcomes in the relevant recent literature

\begin{tabular}{|c|c|c|c|c|}
\hline Authors & Year & $\begin{array}{l}\text { Number of } \\
\text { patients }\end{array}$ & $\begin{array}{l}\text { Ailment - } \\
\text { Surgical Treatment }\end{array}$ & Conclusion \\
\hline Moran et al. & 1995 & 116 & $\begin{array}{l}97 \text { cases - idiopathic scoliosis } \\
19 \text { cases - spinal deformity of } \\
\text { other etiology }\end{array}$ & $\begin{array}{l}\text { PABD in combination with other blood } \\
\text { conservation techniques significantly de- } \\
\text { creased ABT requirement }\end{array}$ \\
\hline Ridgeway et al. & 2003 & 45 & Scoliosis surgery & $\begin{array}{l}\text { PABD is effective in terms of safety and } \\
\text { reducing ABT requisites }\end{array}$ \\
\hline Bess et al. & 2006 & 123 & AIS surgery & $\begin{array}{l}\text { The majority of patients were transfused } \\
\text { at a high Hct }(>30) \text { or wasted one autolo- } \\
\text { gous unit minimum, demonstrating that } \\
\text { guidelines for PABD utilization should } \\
\text { be reviewed }\end{array}$ \\
\hline Boniello et al. & 2016 & 125 & Posterior spinal fusion for AIS & $\begin{array}{l}\text { PABD is not fundamentally responsible for } \\
\text { preoperative Hct levels decrement, being } \\
\text { also associated with remarkably lower } \\
\text { ABT potentiality }\end{array}$ \\
\hline Kelly et al. & 2016 & 418 & Adult spinal deformity surgery & $\begin{array}{l}\text { PABD is not associated with ABT rates } \\
\text { decrement, leading also to increased peri- } \\
\text { operative transfusion potentiality }\end{array}$ \\
\hline Sanpera et al. & 2016 & 37 & AIS surgery & $\begin{array}{l}\text { PABD is related to significant procedure } \\
\text { costs and redundant blood transfusions }\end{array}$ \\
\hline
\end{tabular}

Table 3. CS recruitment reports in the literature

\begin{tabular}{|c|c|c|c|c|}
\hline Authors & Year & $\begin{array}{l}\text { Number of } \\
\text { patients }\end{array}$ & $\begin{array}{l}\text { Ailment - } \\
\text { Surgical Treatment }\end{array}$ & Conclusion \\
\hline Bowen et al. & 2010 & 54 & $\begin{array}{l}\text { Posterior spinal fusion for Idio- } \\
\text { pathic Scoliosis }\end{array}$ & $\begin{array}{l}\text { Intraoperative CS is associated with } \\
\text { decreased ABT rates, especially in con- } \\
\text { ditions of long operation duration and } \\
\text { significant intraoperative hemorrhage }\end{array}$ \\
\hline Carless et al. & 2010 & 75 RCTs & $\begin{array}{l}\text { Adult elective cardiac and or- } \\
\text { thopaedic surgeries }\end{array}$ & $\begin{array}{l}\text { CS is capable of reducing ABT possibility, } \\
\text { featuring alongside not a negative effect } \\
\text { in clinical outcomes }\end{array}$ \\
\hline Ersen et al. & 2012 & 45 & Posterior spinal fusion for AIS & $\begin{array}{l}\text { Intraoperative } \mathrm{CS} \text { is related to decreased } \\
\text { perioperative } \mathrm{ABT} \text { potentiality }\end{array}$ \\
\hline Akgül et al. & 2014 & 33 & AIS surgery & $\begin{array}{l}\text { Intraoperative CS recruitment is not ca- } \\
\text { pable of ABT rates reduction in surgical } \\
\text { treatment of AIS }\end{array}$ \\
\hline Carey et al. & 2015 & 167 & Posterior spinal fusion for AIS & $\begin{array}{l}\text { Intra- and postoperative CS is correlated } \\
\text { with significantly lower perioperative } \\
\text { transfusion potentiality }\end{array}$ \\
\hline Liu et al. & 2017 & $\begin{array}{c}562 \\
(7 \text { studies })\end{array}$ & Scoliosis surgery & $\begin{array}{l}\text { Intraoperative CS remarkably decreases } \\
\text { peri- and post-operative ABT in scolio- } \\
\text { sis surgery, being also associated with } \\
\text { enhanced Hct and Hb levels in the first } \\
\text { postoperative day }\end{array}$ \\
\hline Oliveira et al. & 2017 & 42 & $\begin{array}{l}\text { Posterior arthrodesis with instru- } \\
\text { mentation for AIS }\end{array}$ & $\begin{array}{l}\text { CS effectively decreased ABT rates, being } \\
\text { also cost-effective }\end{array}$ \\
\hline
\end{tabular}


associated with significantly lesser cost, in contrast to $\mathrm{ABT}^{3}$ Liu et al. published a meta-analysis on intraoperative CS outcomes, concluding that Hct and $\mathrm{Hb}$ levels were remarkably increased on the first postoperative day, demonstrating thus that intraoperative CS mainly contributed to patients hemodynamic stabilization. In addition, intraoperative CS is not related to intraoperative transfusion complications rate increment. ${ }^{2}$ Akgül et al. were the only researchers to claim that Cell-saver utilization was not correlated with ABT rates decrement. ${ }^{12}$ The limited number of patients enrolled may be responsible for this differentiation.

In our study, PABD implementation (in conjunction with intraoperative CS) was found to have a significant impact on preoperative $\mathrm{Hct}$ and $\mathrm{Hb}$ values. The patients in group B were subjected to PIF with lower preoperative Hct and $\mathrm{Hb}$ values in comparison with group $\mathrm{A}$, increasing thus the possibility of intraoperative hemodynamic imbalance. Intraoperative transfused blood unit number was significantly higher in group $\mathrm{B}$, even with the additional utilization of intraoperative CS, demonstrating that this imbalance with subsequent required transfusion occurred more frequently in group B. In contrast, $\mathrm{Hct}$ and $\mathrm{Hb}$ levels reflected postoperatively and at discharge were similar to those of the control group. Furthermore, it was also concluded that PABD in conjunction with intraoperative CS is capable of significantly decreasing the ABT rates. Nevertheless, absolute elimination was not accomplished, indicating a relative insufficiency.

Among the limitations of our study are the different commercial types, regarding label and model, of CS system that were utilized for patients. Technical issues as approval of each individual Social Security Funds established the commercial features of utilized CS system. Also, the retrospective character of the study resulted in slight differences at the postoperative treatment of the patients such as exact mobilization date, frequency of Hct check and the volume of intravenous N/S used.

The establishment of particular predictive factors of intraoperative blood loss institutes a realistic necessity. Nevertheless, there is a remarkable differentiation among relevant studies in the literature. Ialenti et al. retrospectively studied 340 patients, concluding that sex, operation duration, as well as preoperative kyphosis represent significant predictors of intraoperative blood loss. ${ }^{20} \mathrm{Kwan}$ et al. also speculated that a number of attending surgeons may be remarkably associated with intraoperative hemor- rhage volume. Two-surgeon strategy was concluded to be related to shorter intraoperative times, lesser intraoperative blood loss and $\mathrm{ABT}$ rates. ${ }^{21}$ Moreover, preoperative $\mathrm{Hb}$ level and estimated intraoperative hemorrhage have been reported to institute autonomous predictive factors of transfusion requirement. ${ }^{22}$ Miri et al. also concluded that operation duration, age at surgery, number of fused levels and mean intraoperative Systolic Blood Pressure designate additional predictors of intraoperative blood loss in lumbosacral surgeries. ${ }^{23}$

To our best knowledge, this is the first study in the literature to report particular outcomes of recruitment of PABD in conjunction with intraoperative CS in PIF surgery for AIS. Our results demonstrated that PABD with CS intraoperatively is associated to statistically significant $\mathrm{ABT}$ rates decrement, in comparison with the control group. However, this combination was not capable of perfect $\mathrm{ABT}$ requisites elimination. Design of further studies with wider population sizes and alongside cost-effectiveness assessment is essential in order to identify the especial impact of PABD in combination with intraoperative CS utility in perioperative blood management of patients subjected to PIF for AIS.

\section{REFERENCES}

1. Lykissas MG, Crawford AH, Chan G, et al. The effect of tranexamic acid in blood loss and transfusion volume in adolescent idiopathic scoliosis surgery: a single-surgeon experience. J Child Orthop 2013;7(3):245-9.

2. Liu JM, Fu BQ, Chen WZ, et al. Cell salvage used in scoliosis surgery: is it really effective? World Neurosurg 2017;101:568-76.

3. Oliveira JAA, Façanha Filho FAM, Fernandes FV, et al. Is cell salvage cost-effective in posterior arthrodesis for adolescent idiopathic scoliosis in the public health system? J Spine Surg 2017;3(1):2-8.

4. Pham JC, Catlett CL, Berenholtz SM, et al. Change in use of allogeneic red blood cell transfusions among surgical patients over time. J Am Coll Surg 2008;207(3):352-9.

5. Choi HY, Hyun SJ, Kim KJ, et al. Effectiveness and safety of tranexamic acid in spinal deformity surgery. J Korean Neurosurg Soc 2017;60(1):75-81.

6. Oetgen ME, Litrenta J. Perioperative blood management in pediatric spine surgery. J Am Acad Orthop Surg 2017;25(7):480-8.

7. Anand N, Idio FG Jr, Remer S, et al. The effects of perioperative blood salvage and autologous blood donation on transfusion requirements in scoliosis surgery. J Spinal Disord 1998;11(6):532-4. 
8. Ridgeway S, Tai C, Alton P, et al. Pre-donated autologous blood transfusion in scoliosis surgery. J Bone Joint Surg Br 2003;85(7):1032-6.

9. Boniello AJ, Verma K, Peters A, et al. Pre-operative autologous blood donation does not affect preincision hematocrit in adolescent idiopathic scoliosis patients. A retrospective cohort of a prospective randomized trial. Int J Spine Surg 2016;10:27.

10. Sanpera Jr. I, Burgos-Flores J, Garcia V, et al. Is autologous blood transfusion cost effective in adolescent idiopathic scoliosis? Acta Orthop, Belg 2016;82:901-6.

11. Carey PA, Schoenfeld AJ, Cordill RD, et al. A comparison of cell salvage strategies in posterior spinal fusion for adolescent idiopathic scoliosis. J Spinal Disord Tech 2015;28(1):1-4.

12. Akgül T, Dikici F, Ekinci M, et al. The efficacy of cell saver method in the surgical treatment of adolescent idiopathic scoliosis. Acta Orthop Traumatol Turc 2014;48(3):303-6.

13. Bess RS, Lenke LG, Bridwell KH, et al. Wasting of preoperatively donated autologous blood in the surgical treatment of adolescent idiopathic scoliosis. Spine (Phila Pa 1976) 2006;31(20):2375-80.

14. Kelly MP, Zebala LP, Kim HJ, et al. Effectiveness of preoperative autologous blood donation for protection against allogeneic blood exposure in adult spinal deformity surgeries: a propensity-matched cohort analysis. J Neurosurg Spine 2016;24(1):124-30.

15. Moran MM, Kroon D, Tredwell SJ, et al. The role of autologous blood transfusion in adolescents undergoing spinal surgery. Spine (Phila Pa 1976) 1995;20(5):532-6.

16. Bowen RE, Gardner S, Scaduto AA, et al. Efficacy of intraoperative cell salvage systems in pediatric idiopathic scoliosis patients undergoing posterior spinal fusion with segmental spinal instrumentation. Spine (Phila Pa 1976) 2010;35(2):246-51.

17.Carless PA, Henry DA, Moxey AJ, et al. Cell salvage for minimising perioperative allogeneic blood transfusion. Cochrane Database Syst Rev 2010;(3):CD001888.

18. Ersen O, Ekinc1 S, Bilgic S, et al. Posterior spinal fusion in adolescent idiopathic scoliosis with or without intraoperative cell salvage system: a retrospective comparison. Musculoskelet Surg 2012;96(2):107-10.

19. Du L, Zheng J, Tang Y. High-sensitivity to heparin associates with cell salvage transfusion in adolescent idiopathic scoliosis patient undergoing posterior spinal fusion. Int J Clin Exp Med 2014;7(8):2380-2.

20. Ialenti MN, Lonner BS, Verma K, et al. Predicting operative blood loss during spinal fusion for adolescent idiopathic scoliosis. J Pediatr Orthop 2013;33(4):372-6.

21. Kwan MK, Chiu CK, Chan CY. Single vs two attending senior surgeons: assessment of intra-operative blood loss at different surgical stages of posterior spinal fusion surgery in Lenke 1 and 2 adolescent idiopathic scoliosis. Eur Spine J 2017;26(1):155-61.

22. Ohrt-Nissen S, Bukhari N, Dragsted C, et al. Blood transfusion in the surgical treatment of adolescent idiopathic scoliosis-a single-center experience of patient blood management in 210 cases. Transfusion 2017;57(7):1808-17.

23. Miri M, Farzanegan G, Khosravi N, et al. Research article predictive factors of blood loss and hospital stay in patients with major lumbosacral surgeries: a multi-center, prospective, cross-sectional survey. Arch Neurosci 2015;2(3):e22804.

24. Maruyama T, Takeshita K. Surgical treatment of scoliosis: a review of techniques currently applied. Scoliosis 200818;3:6.

25.Lenke LG, Kuklo TR, Sucato DJ, et al. Spinal Deformity Study Group. Pedicle screw constructs provide superior thoracic rib hump and lumbar prominence correction following adolescent idiopathic scoliosis surgery. Spine 2009;10:56. 
Периоперационный контроль за кровью в время заднего инструментального спондилодеза при лечении подросткового идиопатического сколиоза: авторское исследование и краткий обзор литературы

\author{
Ламприни Катраница ${ }^{1}$, Николаос Гкантсиникудис ${ }^{2}$, Стилианос Капетанакис ${ }^{2}$, Георгиос \\ Каритудис ${ }^{2}$, Анастасиос Кристодолу ${ }^{1}$, Панайотис Гивисис ${ }^{1}$ \\ ${ }^{1}$ Первая кафедра ортопедии, Больница общего профиля Г. Папаниколау, Медицинский факультет, Салоникский универ- \\ ситет имени Аристотеля, Салоники, Греция \\ ${ }^{2}$ Кафедра хирургии позвоночника, Европейский медицинский центр Интербалкан, Салоники, Греция
}

Адрес для корреспонденции: Ламприни Катраница, Первая кафедра ортопедии, Больница общего профиля Г. Папаниколау, Медицинский факультет, Салоникский университет имени Аристотеля, Эксохи, 57010

Салоники, Греция

E-mail: katranitsalamprini@gmail. com

Tel: 00306944838199

Дата получения: 04 сентября.

2017

Дата приемки: 06 октября 2017 Дата онлайн публикации: 20 ноября 2017

Дата публикации: 30 июня 2018

Ключевые слова: сколиоз, переливание крови, контроль за кровью, интраоперационная реинфузия крови, предоперационное аутологичное донорство крови

Образец цитирования: Katranitsa L, Gkantsinikoudis N, Kapetanakis S, Charitoudis G, Christodoulou A, Givissis P. Perioperative blood management in posterior instrumented fusion for adolescent idiopathic scoliosis: an original study and short review of the literature. Folia Med (Plovdiv) 2018;60(2):200-7.

doi: 10.1515/folmed-2017-0100
Введение: Потенциальные опасности аллогенного переливания крови хорошо представлены в литературе. Однако мало что известно о результатах совместного применения различных методов сохранения крови и о результатах в предотвращении аллогенного переливания крови (АПК) при операции сколиоза.

Цель: Сообщить о конкретных результатах использования предоперационного аутологичного донорства крови (ПАДК) и интраоперационной реинфузии крови (ИРК) с целью минимизации потребности в АПК.

Материалы и методы: В период с 1989 по 2012 год 107 пациентам была проведен задний инструментальный спондилодез (ЗИС) для коррекции подросткового идиопатического сколиоза (ПИС). Проведена ретроспективная оценка. Пациенты были разделены на две группы, в соответствии с используемым методом: группа А с только аллогенным переливанием крови (АПК) и группа В, где применялись ПАДК с ИРК во время операции. Показатели гематокрита и гемоглобина были измерены до операции, после операции и при выписке. Переменные, которые нами были измерены, включали также пол, возраст, уровни спондилодеза, количество предварительно выделенных единиц крови, необходимые переливающиеся единицы крови (ПЕК), а также частота АПК между этими двумя группами.

Результаты: Более 70\% переливаний в обеих группах были необходимы во время операции. В группе А было перелито в среднем 2,4 единицы на одного пациента, а АПК - 76\%. В отличие от этого, в группе В в среднем 4,5 единицы на одного пациента было перелито, но показатель АПК составлял всего 7,3\%, а остальные 92,7\% были аутологичной. Однако потерянная аутологичная кровь достигла 24,9\%.

Заключение: Наши результаты показали, что ПАДК с интраоперационной реинфузией крови (ИРК) ассоциируется со статистически значимым снижением частоты АПК, но комбинация этих методов не может обеспечить избежание АПК. 